\title{
MUCL1 wt Allele
}

National Cancer Institute

\section{Source}

National Cancer Institute. MUCL1 wt Allele. NCI Thesaurus. Code C54291.

Human MUCL1 wild-type allele is located in the vicinity of $12 \mathrm{q}$ and is approximately $4 \mathrm{~kb}$ in length. This allele, which encodes mucin-like protein 1, may be involved in the modulation of epithelial basement membrane structure. The expression of the gene may be a marker for metastatic breast cancer because it is expressed at elevated levels in breast carcinomas displaying lymph node metastases. 